\title{
LISTS OF SPECIES
}

\section{Amphibia, Anura, Coastal Zone, state of Piauí, Northeastern Brazil.}

\author{
Daniel Loebmann ${ }^{1}$ \\ Ana Cecília Giacometti Mai ${ }^{2}$ \\ ${ }^{1}$ Laboratório de Herpetologia, Programa de Pós-Graduação em Ciências Biológicas (Zoologia), Instituto de \\ Biociências, Universidade Estadual Paulista, Av. 24 A, 1515, Bairro Bela Vista, CEP 13506-900. Rio Claro, SP, Brazil. \\ E-mail: contato@danielloebmann.com \\ ${ }^{2}$ Programa de Pós-graduação em Ciências Biológicas (Zoologia), Departamento de Sistemática e Ecologia, Centro de \\ Ciências Exatas e da Natureza, LAPEC, Universidade Federal da Paraiba, CEP 58059-900. João Pessoa, PB, Brazil.
}

\begin{abstract}
Amphibians are an important component of terrestrial and aquatic freshwater communities worldwide. Especially to the Northern coastal zone of Brazil, the knowledge about amphibian communities is very scarce. We have studied amphibian assemblages along the coastal strip zone of the state of Piauí for two years, covering a distance of ca. $70 \mathrm{~km}$. It was possible to prepare a list of 21 anurans from 6 families (Microhylidae, Hylidae, Leptodactylidae, Cycloramphidae, Leiuperidae, and Bufonidae). All species are common and widely distributed in Brazilian territory, mainly on the Caatinga biome. The results are important to amplify the knowledge on the biodiversity found at the coastal zone of the state of Piauí.
\end{abstract}

\section{Introduction}

Although there are studies reporting on the fauna of amphibians in the environments along the Brazilian coastal zone (e.g. Schineider and Teixeira 2001; Cascon and Borges-Nojosa 2003; Loebmann 2005; Loebmann and Vieira 2005; Juncá 2006), the knowledge of the amphibians communities along the littoral is still very deficient, considering that the coastal zone of Brazil has ca. 8,500 kilometers of extension (Awosika and Marone 2000).

Similar situation can be found in the state of Piauí, where studies on the anuran fauna are limited to the description of two species (Caramaschi and Jim 1983a; b), an expansion of the geographical distribution of one species to the Parque Nacional Sete Cidades (Sete Cidades National Park; Annunziata et al. 2007), and a species list for the coastal dunes from the municipality of Ilha Grande (Silva et al. in press).

The entire coastal zone of the state lies within the Área de Proteção Ambiental (APA) do Delta do Parnaiba (Environmental Protection Area of the Parnaíba River Delta). Even so, human activities like constructions (e.g. houses, roads, tourist accommodations, and shrimp farms), deforestation, and pollution have often caused loss or damage of natural habitats occupied by amphibians and other taxa. This is a worldwide problem that has already caused the decline of some species (Brooks et al. 2002), especially in coastal zones, where human population is concentrated and increasing quickly. In this context, biological inventories are very important to provide support for actions of coastal management. In order to contribute to the knowledge of the amphibian fauna, a list of species that occur along the coastal zone of the state of Piauí is presented.

\section{Material and Methods}

We sampled seven sites of the coastal zone of the state of Piauí, located in the municipalities of Parnaíba, Luís Correia, and Cajueiro da Praia, between the coordinates $02^{\circ} 09^{\prime} \mathrm{S}, 41^{\circ} 15^{\prime} \mathrm{W}$ and $02^{\circ} 45^{\prime} \mathrm{S}, 41^{\circ} 51^{\prime} \mathrm{W}$ (Figure 1). The regional climate presents warm temperatures during all the year (from 22 to $33{ }^{\circ} \mathrm{C}$ ), and is characterized by a marked dry period with precipitation below 100 $\mathrm{mm}$ between June and December, and a rainy period in the first months of the year (Figure 2). The coastal zone is basically characterized by the presence of coastal dunes and mangrove forests, which are limited in the south by a physiognomy known as secondary stationary vegetation of Cerradão (CEPRO 1996). Although Ab'Sáber (1977) classified this area as a transitional zone between the biomes of Caatinga and Cerrado, the composition of its herpetofauna is clearly related to the Caatinga, as showed below. 


\section{LISTS OF SPECIES}

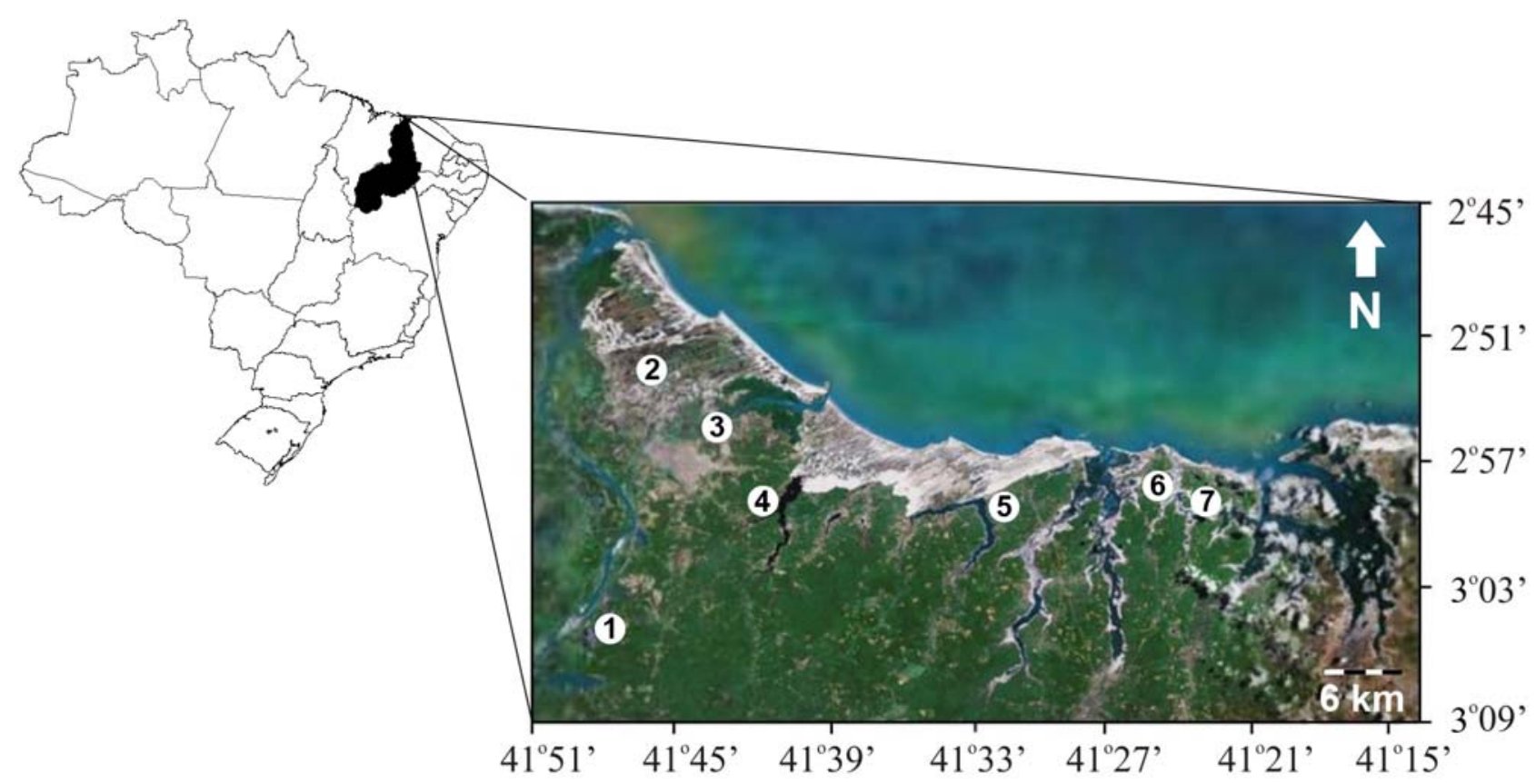

Figure 1. Study area. Satellite image of the coastal zone of the state of Piauí, Brazil, showing the sites investigated.

Samplings were conducted between 2005 and 2007, as follows: bimonthly samplings from January to December 2005 in the surroundings of the town of Parnaíba (Site 3, Figure 1); bimonthly samplings from June 2006 to July 2007 in the municipality of Cajueiro da Praia (Sites 6 and 7, Figure 1), and non-regular, intensified collections during the months with higher precipitation (February to May) in all sites. We investigated permanent and temporary ponds in mangrove, coastal dunes, and Cerradão borders using active search and vocalization activity monitoring. Taxonomy and species group allocation follows Faivovich et al. (2005), Frost et al. (2006), and Chaparro et al. (2007). Voucher specimens were deposited in the Herpetological Collection of the Universidade Federal da Paraiba (UFPB) and in the Célio F. B. Haddad Amphibian Collection (CFBH), Universidade Estadual Paulista (UNESP), Rio Claro, São Paulo.

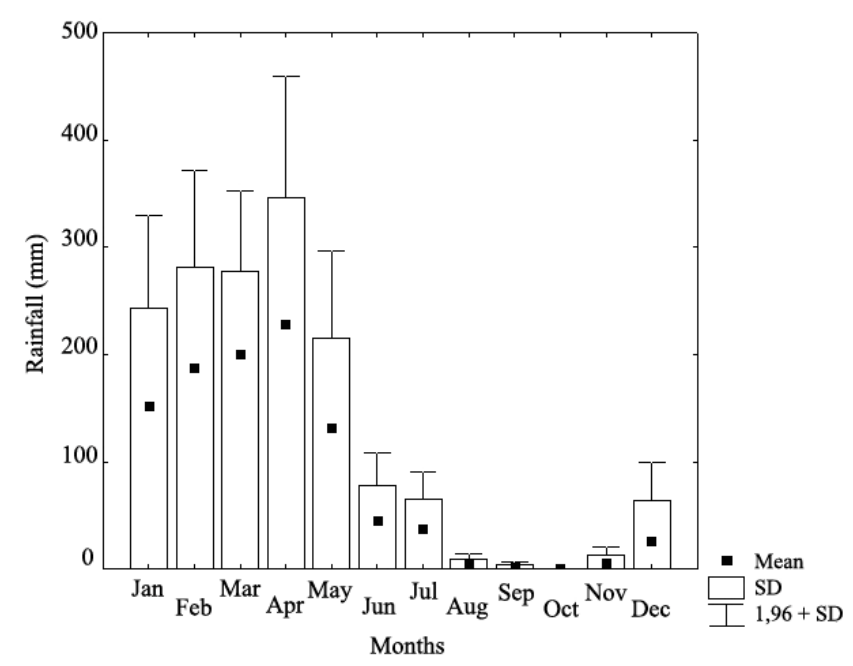

Figure 2. Mean, standard deviation (SD), and 95 $\%$ confidence interval $(1.96+\mathrm{SD})$ of rainfall data (period 1990 to 2005). Font: Meteorological station of the Embrapa Meio-Norte, Parnaíba, Piauí, Brazil. 


\section{LISTS OF SPECIES}

At least one individual of each species was photographed. Images were made by the first author with a Canon PowerShot A620 digital camera (7.0 megapixels and 180 dpi of image resolution) and a Sony DSC-F828 digital camera (8.0 megapixels and 72 dpi of image resolution).

\section{Results and Discussion}

A total of 21 species (Figures 3-6) from six anuran families was found on the coastal zone of the state of Piauí (Table 1). Hylidae presented nine species and was the richest family, followed by Leptodactylidae and Leiuperidae, both with four species. Although Dendropsophus soaresi and Dermatonotus muelleri were not collected during our field samplings, it is likely that they also occur in the coastal zone of Piauí, since both species have already been observed in areas near the Caatinga on the southern region of the state.

The amphibian fauna of the coast of Piaui and neighbouring states is virtually unknown. Silva et al. (in press) recorded the presence of 14 species for the coastal dunes of the municipality of Ilha Grande, Piauí. Their study is very important in order to complement the present one, since our study included no samples in Ilha Grande. Silva et al. (in press) also report three species not recorded in the present study (Elachistocleis ovalis, Leptodactylus ocellatus, and L. pustulatus). However, we consider that the proper identifications for specimens referred to as E. ovalis and $L$. ocellatus in Silva et al. (in press) are $E$. piauiensis and L. macrosternum. Therefore, the anuran fauna of the coastal zone of Piaui is characterized by at least 22 species. For the neighboring state of Ceará, 20 species are known from the coastal areas (Cascon and Borges-Nojosa 2003). A comparison of the anuran fauna from the coastal zones of the two states shows a great similarity in species number and composition; only Dendropsophus soaresi, Leptodactylus mystaceus, and Scinax fuscomarginatus were not found in the coastal zone of Piauí.

The number of species found in our study is also similar to those found in areas of Caatinga in the states of Pernambuco, Ceará, and Paraíba. In these surveys, 18 species were registered for Serra das Almas, a particular protected area in the municipality of Crateús, Ceará (Borges-Nojosa and Cascon 2005), 19 species were registered in two particular protected areas (Maurício Dantas, municipality of Betânia, and Cantidiano Valgueiro, municipality of Floresta) in Pernambuco (Borges-Nojosa and Santos 2005), and 21 species in two areas from the Curimataú valley, Paraíba (Arzabe et al. 2005). At least 11 species (Hypsiboas raniceps, L. fuscus, L. vastus, $L$. macrosternum, L. troglodytes, Phyllomedusa nordestina, Proceratophrys cristiceps, Pleurodema diplolister, Rhinella granulosa, R. jimi, and Scinax $x$-signatus) are common for all study sites, evidencing a strong influence of the Caatinga biome in the composition of the anuran fauna of the coastal zone of Piauí.

All species found are typical of open areas and show wide distribution (see Table 1). Some species such as Dendropsophus minutus, $L$. fuscus, Physalaemus cuvieri, and Trachycephalus venulosus, present ambiguous taxonomic status, and are probably species complexes (Wynn and Heyer 2001; Eterovick and Sazima 2004; Hawkins et al 2007). Others can possibly converge to new species, like Dendropsophus gr. microcephalus and Pseudopaludicola gr. falcipes. Thus, the distributional data shown in Table 1 may alter for small areas, as it has recently occurred for Phyllomedusa nordestina, previously recognized as $P$. hypochondrialis (Caramaschi 2006), and for Leptodactylus vastus, previously recognized as $L$. labyrinthicus and now revalidated (Heyer 2005).

Regarding to the distribution of the species among the studied habitats, two patterns were observed (Table 1). Some species are widely distributed and commonly found in coastal and Cerradão areas. Other species are restricted to temporary pools in flooded Cerradão areas near the coast. These results are important to enhance the knowledge on the fauna in the APA do Delta do Parnaiba and to improve the comprehension of the distribution patterns of amphibian species in Caatinga areas. 


\section{LISTS OF SPECIES}

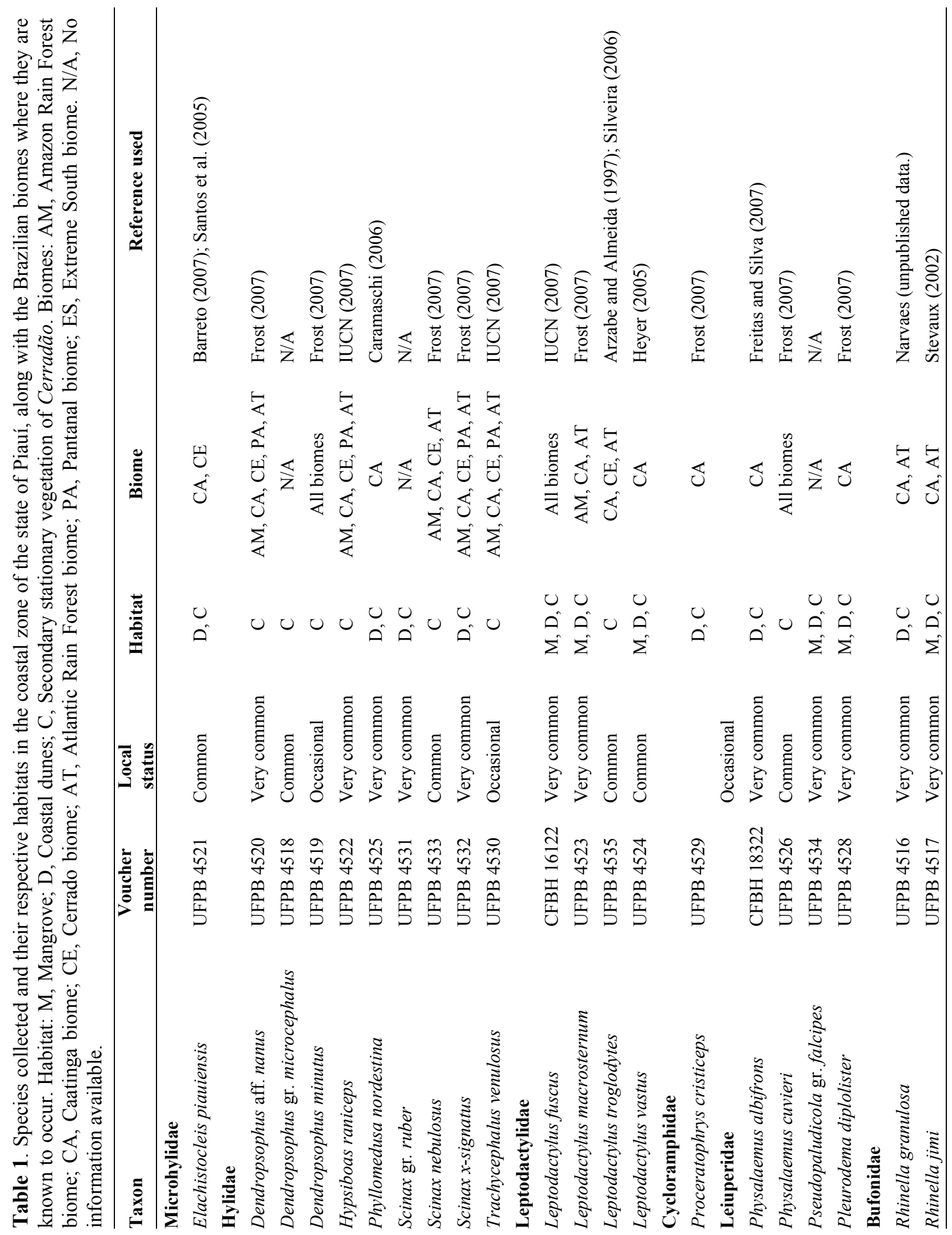


Check List 4(2): 161-170, 2008.

ISSN: $1809-127 \mathrm{X}$

\section{LISTS OF SPECIES}
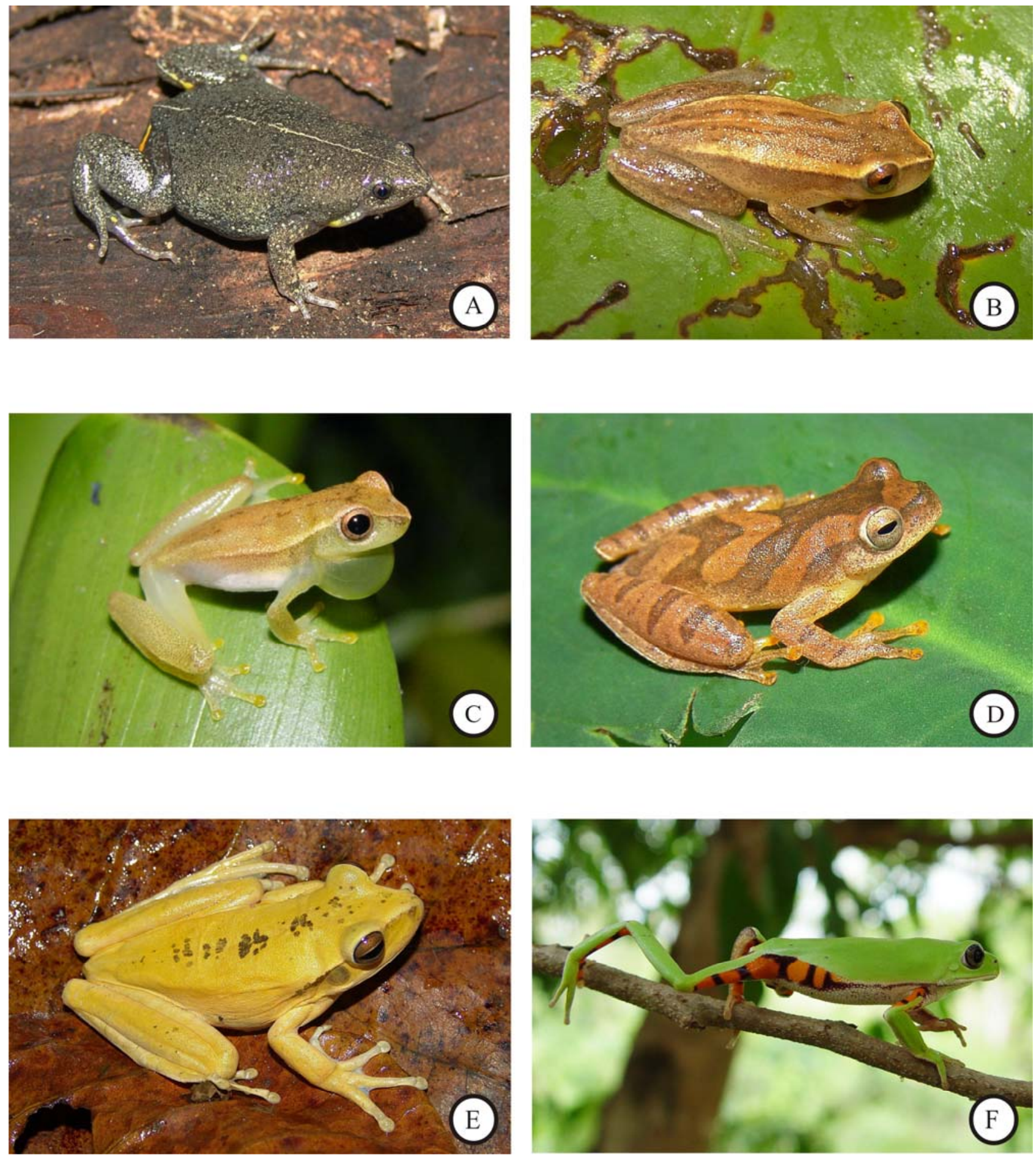

Figure 3. Anuran species recorded on the coastal zone of the state of Piauí, Brazil, on samples made between 2005 and 2007. Family Microhylidae: A, Elachistocleis piauiensis. Family Hylidae: B, Dendropsophus aff. nanus; C, Dendropsophus gr. microcephalus; D, Dendropsophus minutus; E, Hypsiboas raniceps; F, Phyllomedusa nordestina. 
Check List 4(2): 161-170, 2008.

ISSN: $1809-127 \mathrm{X}$

\section{LISTS OF SPECIES}
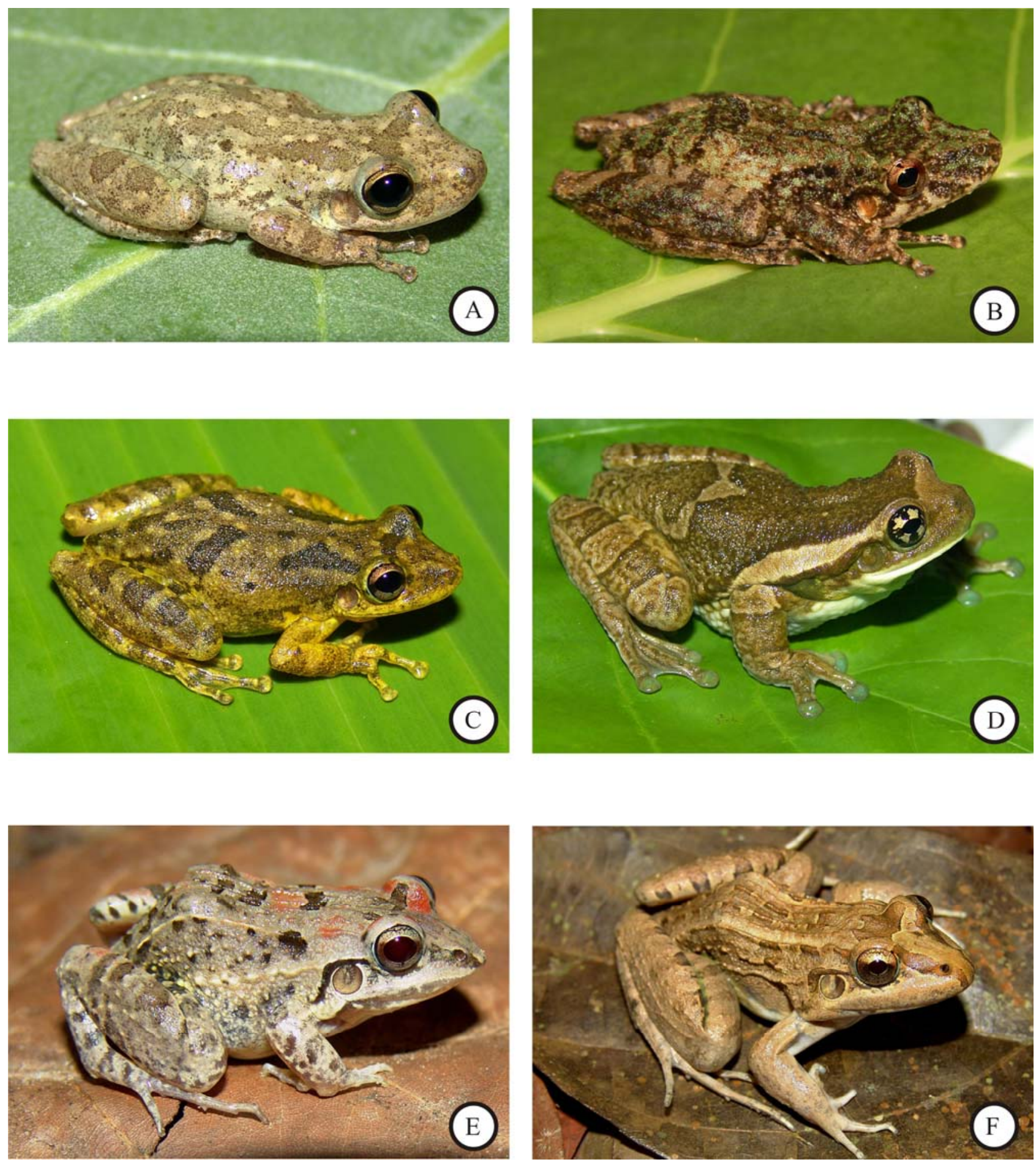

Figure 4. Anuran species recorded on the coastal zone of the state of Piauí, Brazil, on samples made between 2005 and 2007. Family Hylidae: A, Scinax gr. ruber; B, Scinax nebulosus; C, Scinax x-signatus; D, Trachycephalus venulosus. Family Leptodactylidae: E, Leptodactylus fuscus; F, Leptodactylus macrosternum. 
Check List 4(2): 161-170, 2008.

ISSN: 1809-127X

\section{LISTS OF SPECIES}
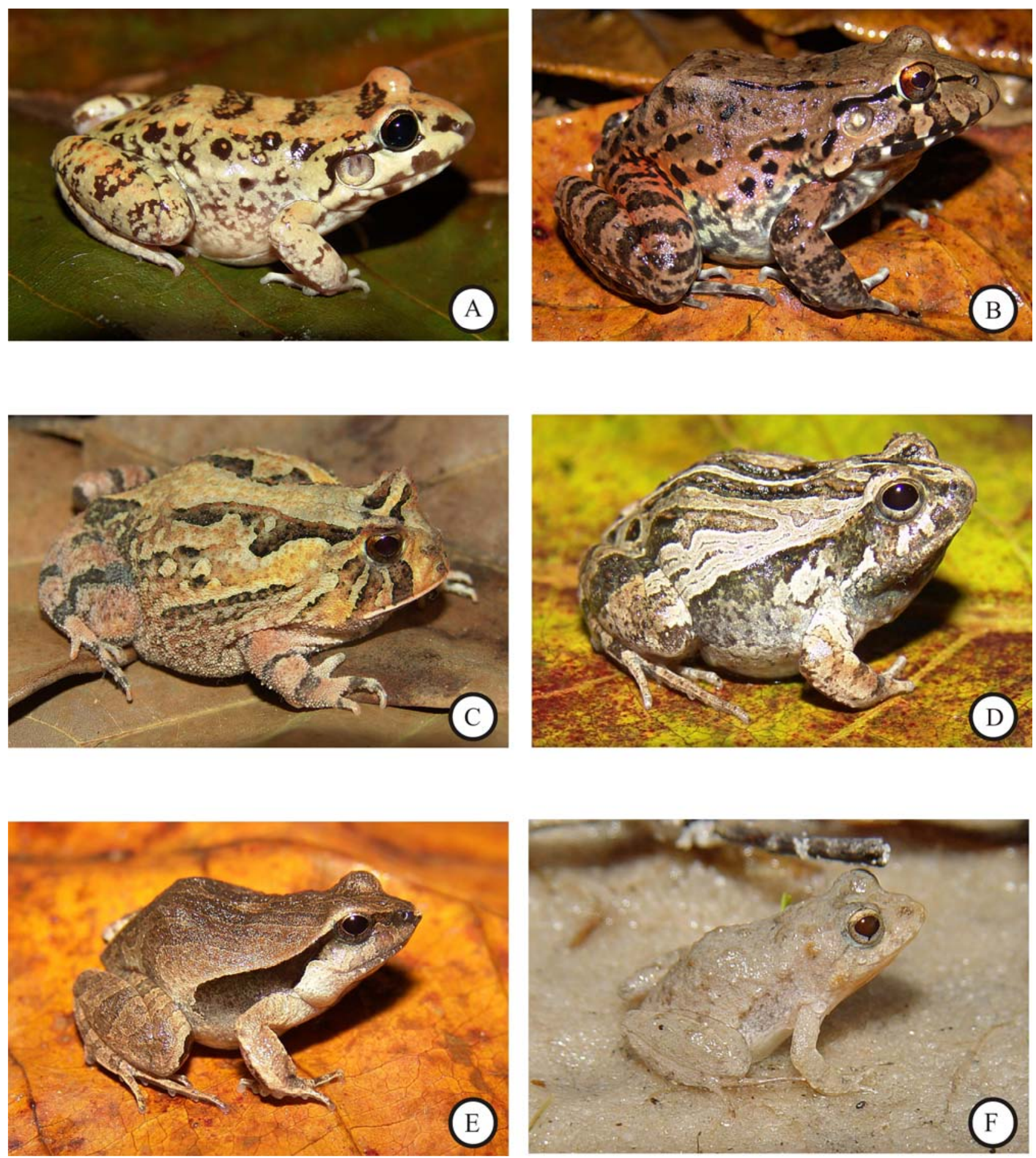

Figure 5. Anuran species recorded on the coastal zone of the state of Piauí, Brazil, on samples made between 2005 and 2007. Family Leptodactylidae: A, Leptodactylus troglodytes; B, Leptodactylus vastus. Family Cycloramphidae: C, Proceratophrys cristiceps. Family Leiuperidae: D, Physalaemus albifrons; E, Physalaemus cuvieri; F, Pseudopaludicola gr. falcipes. 


\section{LISTS OF SPECIES}
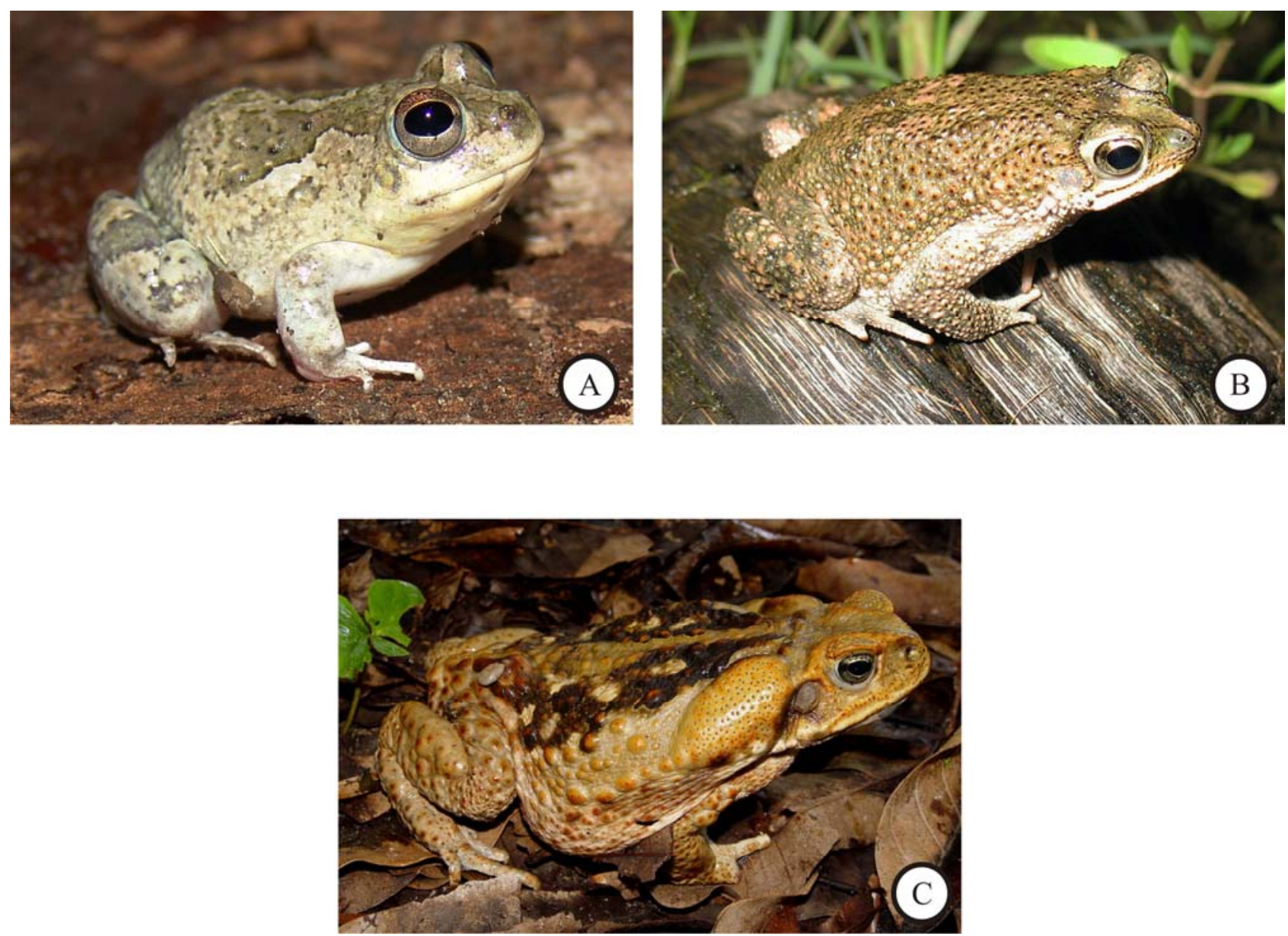

Figure 6. Anuran species recorded on the coastal zone of the state of Piauí, Brazil, on samples made between 2005 and 2007. Family Leiuperidae: A, Pleurodema diplolister. Family Bufonidae: B, Rhinella granulosa; C, Rhinella jimi.

\section{Acknowledgments}

We are grateful to the coordinators of Embrapa Meio-Norte, Parnaíba, who permitted the use of meteorological data under their care and access to the farm administered by this institution for some of our surveys; Gilda V. Andrade (Universidade Federal do Maranhão, São Luís, Maranhão), Bruno V. S. Pimenta (Universidade Federal de Minas Gerais, Belo Horizonte, Minas Gerais), and an unidentified referee for suggestions on earlier versions of the manuscript; James Tony Lee (Universidade Federal do Pará, Belém, Pará) and Maria Cristina Oddone (Universidade Estadual Paulista Júlio de Mesquita Filho, Rio Claro, São Paulo) for revising and improving the manuscript English; Igor Joventino Roberto (Associação de Pesquisa e Preservação de Ecossistemas Aquáticos), Paulo Cascon (Universidade Federal do Ceará), Guilherme R. da Silva, Clarenice L. Dos Santos, Margareth R. Alves, Suzy D. V. de Sousa, and Bruno B. Annunziata (Universidade Estadual do Piaui) for allowing access to their non-published manuscripts. 


\section{LISTS OF SPECIES}

\section{Literature cited}

Ab'Sáber, A. N. 1977. Os domínios morfoclimáticos na América do Sul. Primeira aproximação. Geomorfologia 52: 1-21.

Annunziata, B. B., W. M. Fontenele, I. S. Castro, R. F. Gurgel, and K. A. Nascimento. 2007. Amphibia, Anura, Hylidae, Dendropsophus rubicundulus: Distribution extension. Check List 3(3): 242-243.

Arzabe, C., and C. C. Almeida. 1997. Life history notes on Leptodactylus troglodytes (Anura, Leptodactylidae) in northeastern Brazil. AmphibiaReptilia 18: 211-215.

Arzabe, C., G. Skuk, G. G. Santana, F. R. Delfim, Y. C. C. Lima, and S. H. F Abrantes. 2005. Herpetofauna da Área de Curimataú, Paraíba; p. 259-274 In F. S. Araújo, M. J. N. Rodal, and M. R. V. Barbosa (ed.). Análise das Variações da Biodiversidade do Bioma Caatinga. Brasília: Ministério do Meio Ambiente.

Awosika, L. and E. Marone. 2000. Scientific needs to assess the health of the oceans in coastal areas: a perspective of developing countries. Ocean \& Coastal Management 43: 781-791.

Barreto, L. 2007. Cerrado Norte do Brasil / North Cerrado of Brazil. Pelotas: União Sul-Americana de Estudos da Biodiversidade. 380 p.

Borges-Nojosa, D. M. and P. Cascon. 2005. Herpetofauna da Área Reserva da Serra das Almas, Ceará; p. 243-258 In F. S. Araújo, M. J. N. Rodal, and M. R. V. Barbosa (ed.). Análise das Variações da Biodiversidade do Bioma Caatinga. Brasília: Ministério do Meio Ambiente.

Borges-Nojosa, D. M. and E. M. Santos. 2005. Herpetofauna da Área de Betânia e Floresta, Pernambuco; p. 275-289 In F. S. Araújo, M. J. N. Rodal, and M. R. V. Barbosa (ed.). Análise das Variações da Biodiversidade do Bioma Caatinga. Brasília: Ministério do Meio Ambiente.

Brooks, T. M., R. A. Mittermeier, C. G. Mittermeier, G. A. B. da Fonseca, A. B. R., W. R. Konstant, P. Flick, J. Pilgrim, S. Oldfield, G. Magin, and C. Hilton-Taylor. 2002. Habitat loss and extinction in the hotspots of biodiversity. Conservation Biology 16 (4): 909-923.

Caramaschi, U. 2006. Redefinição do grupo de Phyllomedusa hypochondrialis, com redescrição de P. megacephala (Miranda-Ribeiro, 1926), revalidação de $P$. azurea Cope, 1862 e descrição de uma nova espécie (Amphibia, Anura, Hylidae). Arquivos do Museu Nacional, Rio de Janeiro 64(2): 159-179.

Caramaschi, U. and J. Jim. 1983a. A new microhylid frog, genus Elachistocleis (Amphibia, Anura) from northeastern Brazil. Herpetologica 39(4): 390-394.

Caramaschi, U. and J. Jim. 1983b. Uma nova espécie de Hyla do grupo marmorata do nordeste brasileiro
(Amphibia, Anura, Hylidae). Revista Brasileira de Biologia 43: 195.

Cascon, P. and D. M. Borges-Nojosa. 2003. Anfíbios; p. 125 In A. A. Campos, A. Q. Monteiro, C. Monteiro-Neto, and M. Pollete, (ed.). A Zona Costeira do Ceará: Diagnóstico para a Gestão Integrada. Fortaleza: Gráfica e Editora Pouchain Ramos.

CEPRO. 1996. Macrozoneamento Costeiro do Estado do Piauí: Relatório ambiental e sócio-econômico. Teresina: Fundação CEPRO: 221 p.

Chaparro, J. C., J. B. Pramuk, and A. G. Gluesenkamp. 2007. A new species of arboreal Rhinella (Anura: Bufonidae) from cloud forest of Southeastern Peru. Herpetologica 63(2): 203-212.

Eterovick, P. and I. Sazima. 2004. Anfíbios da Serra do Cipó, Minas Gerais, Brasil. Belo Horizonte: Editora PUC Minas. $152 \mathrm{p}$.

Faivovich, J., C. F. B. Haddad, P. C. A. Garcia, D. R. Frost, J. A. Campbell, and W. C. Wheeler. 2005. Systematic review of the frog family Hylidae, with special reference to Hylinae: Phylogenetic analysis and taxonomic revision. Bulletin of the American Museum of Natural History 294: 1-240.

Freitas, M. A. and T. F. S. Silva. 2007. A Herpetofauna das Caatingas e áreas de altitude do Nordeste Brasileiro. Pelotas: União Sul-Americana de Estudos da Biodiversidade. 388 p.

Frost, D. R. 2007. Amphibian Species of the World: an online reference. Version 5.0. Electronic Database accessible at http://research.amnh.org/ herpetology/ amphibia/index.html. New York: American Museum of Natural History. Captured on 14 May 2007.

Frost, D. R., T. Grant, J. Faivovich, R. H. Bain, A. Haas, C. F. B. Haddad, R. O. de Sá, A. Channing, M. Wilkison, S. C. Donnelan, C. J. Raxworthy, J. A. Campbell, B. L. Blotto, P. Moler, R. C. Drewes, R. A. Nussbaum, J. D. Lynch, D. M. Green, and W. C. Wheeler. 2006. The Amphibian Tree of Life. Bulletin of the American Museum of Natural History 297: 1-370.

Hawkins, M. A., J. W. Sites, and B. P. Noonan. 2007. Dendropsophus minutus (Anura: Hylidae) of the Guiana Shield: using DNA barcodes to assess identity and diversity. Zootaxa 1540: 61-67.

Heyer, W. R. 2005. Variation and taxonomic clarification of the large species of the Leptodactylus pentadactylus species group (Amphibia: Leptodactylidae) from Middle America, northern South America, and Amazonia. Arquivos de Zoologia 37(3): 269-348.

IUCN, Conservation International and NatureServe. 2007. Global Amphibian Assessment. Eletronic database accessible at http://www.globalamphibians.org. Captured on 14 May 2007. 


\section{LISTS OF SPECIES}

Juncá, F. A. 2006. Diversidade e uso de hábitat por anfíbios anuros em duas localidades de Mata Atlântica, no norte do Estado da Bahia. Biota Neotropica 6(2): 1-8.

Loebmann, D. 2005. Guia Ilustrado: Os anfíbios da região costeira do extremo sul do Brasil. Pelotas: União Sul-Americana de Estudos da Biodiversidade. $76 \mathrm{p}$.

Loebmann, D. and J. P Vieira. 2005. Relação dos anfíbios do Parque Nacional da Lagoa do Peixe, RS, Brasil. Revista Brasileira de Zoologia 22(2): 339341.

Santos, E. M., F. O. Amorim, P. T. de Brito, and I. J. Roberto. 2005. Geographic distribution: Elachistocleis piauiensis. Herpetological Review 36: 332.

Silva, G. R., C. L. Santos, M. R. Alves, S. D. V. Souza, and B. B. Annunziata. In press. Anfíbios das dunas litorâneas do extremo norte do Piauí, Brasil. Sitientibus, Série Ciências Biológicas.
Silveira, A. L. 2006. Anfíbios do município de João Pinheiro, uma área de cerrado no noroeste de Minas Gerais, Brasil. Arquivos do Museu Nacional 64(2): 131-139.

Schineider, J. A. P. and R. L. Teixeira. 1997. Relacionamento entre anfíbios anuros e bromélias da restinga de Regência, Linhares, Espírito Santo, Brasil. Iheringia (Zoologia) 91: 41-48.

Stevaux, M. N. 2002. A new species of Bufo Laurenti (Anura, Bufonidae) from Northeastern Brasil. Revista Brasileira de Zoologia 19(1): 235-242.

Wynn A and W. R. Heyer. 2001. Do geographically widespread species of tropical amphibians exist? An estimate of genetic relatedness within the neotropical frog Leptodactylus fuscus (Schneider 1799) (Anura Leptodactylidae). Tropical Zoology 14: 255-285.

Received January 2008

Accepted April 2008

Published online May 2008 